Nig J. Biotech. Vol. 32 (2017) 15 - 19

ISSN: 01891731

Available online at

http://www.ajol.info/index.php/njb/index

and www.biotechsocietynigeria.org

DOI: http://dx.doi.org/10.4314/njb.v32i1.3

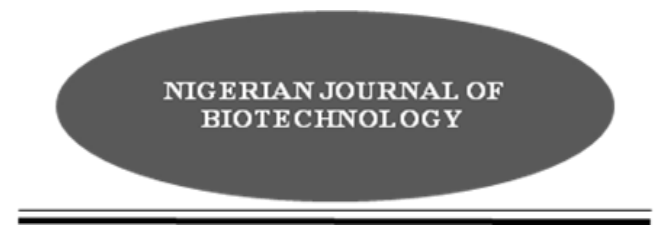

\title{
Reproductive Parameters of the West African Dwarf Bucks Raised in the Guinea Savannah Zone of Nigeria.
}

\author{
Ezihe, C. 0. ${ }^{1}$, Namo, A. V. ${ }^{2}$ and Sule, ${ }^{2}{ }^{2}$ \\ ${ }^{1}$ Department of Veterinary Physiology, Pharmacology and Biochemistry, University of Agriculture, \\ Makurdi. ${ }^{2}$ Department of Animal Production, University of Agriculture, Makurdi
}

\begin{abstract}
(Received: 16:10:2016; Accepted: 09:02:2017)

Thirty West African Dwarf (WAD) bucks were evaluated for reproductive parameters in relation to age. The age of the WAD bucks was determined using the dentition estimation method and varied from less than one year to two years. Reproductive samples (scrotal circumference, testicular density, scrotal weight, left and right testicular weights, left and right tunica weights, left and right testicular length, left and right caput epididymal weights, left and right corpus epididymal weights, left and right caudal epididymal weights) from the bucks were collected twice weekly from Modern Market and Wurukum Abattoirs in Makurdi town, Benue State, Nigeria for a period of three months and evaluated at the Anatomy Laboratory, College of Veterinary Medicine, University Agriculture, Makurdi. Scrotal circumference values recorded $(18.97 \pm 1.14,18.57 \pm 0.21$ and $23.90 \pm 1.04 \mathrm{~cm})$ for the bucks that were less than one year were similar with those of the one year old bucks and these values were significantly $(P<0.05)$ lower than values recorded for the two year old bucks. Adhering connective tissues of the testis were carefully trimmed before dissection of the testis and separation of the epididymis. Right and left testicular weights recorded were $48.75 \pm 3.47,56.63 \pm 3.34,68.84 \pm 3.24$ and $43.61 \pm 3.57,53.23 \pm 1.39,64.67 \pm 3.17 \mathrm{~g}$ for the less than one year, one year and two years old bucks respectively. Values of the right and left testicular weights of the less than one year, one year and two years old bucks were significantly $(P<0.05)$ different from one another. These values increased with age of the bucks. Testicular density values of $1.04 \pm 0.03,1.07 \pm 0.03$ and $1.09 \pm 0.03 \mathrm{~g} / \mathrm{cm}^{3}$ were recorded for the various age categories and these values were not significantly different ( $P>0.05$ ) from one another. Right testicular length, left testicular length, right caudal epididymal and left corpus epididymal weight values recorded for the various age brackets were $7.67 \pm 0.21,8.17 \pm 0.18,8.87 \pm 0.27 \mathrm{~cm} ; 7.60 \pm 0.20,8.11 \pm 0.16,8.93 \pm 0.27 \mathrm{~cm} ; 2.40 \pm 2.17$, $2.66 \pm 0.08,3.05 \pm 0.18$ and $0.47 \pm 0.04,0.53 \pm 0.22,0.59 \pm 0.04 \mathrm{~g}$ espectively. Generally, values recorded for the two years old bucks were higher than other values. The result of this study suggests that overall weights of reproductive organs of WAD goats increased with age.
\end{abstract}

Key Words: Reproductive Parameters, West African Dwarf Goats.

Correspondence: chrisezihe@yahoo.com

Introduction

Challenge of inadequate feeding result in reduction of production in certain livestock species like goats, cattle, swine and poultry. These challenges have reflected on the quality and amount of animal protein available for 
human consumption in the third world. Indigenous ram in Nigeria belongs to four distinct breeds: the long- legged Sahel (Balami) found in the arid and Sahel region, the Uda popularly known as the black and white or brown and white found in the Sudano-Sahelian vegetational region, the Yankasa which is the most numerous and widespread found in the guinea savannah and spread to other parts of the country, and finally the hardy, short-legged West African Dwarf sheep restricted to high altitude areas and humid forest of the south(Ibrahim et. al., 2012).

The West African Dwarf(WAD) breed of goats is found throughout the humid forest belts of Nigeria.. The breed is noted for its hardiness, and because it thrives in tse-tsefly humid forest and savannah zones, it is reported to be resistant to trypanosomiasis (Igboeli and Rakha, 1981). Reproductive performance depends upon the normal structure and functions of genital organs of an animal (Siddiqui et. al., 2005). The growth and development of testicular organs in various species of farm animals has been well documented (Orlu and Egbunike, 2010; Osinowo et. al., 1981; Bitto and Egbunike, 2010). Togun and Egbunike (2006) reported that the size of the testis is an indicator of the present and future sperm production in animals. Testicular size and scrotal circumference are closely related to each other and to spermatozoa production in bulls (Almguist et. al., 1962).

Egbunike et. al. (1976) reported that morphometric analysis on the testis of any species or breed is necessary in assessing and estimating qualitative changes in testicular components and spermatogenic functions. The problems of animal malnutrition therefore, gave rise to some research questions such as: how does gonadal sperm reserve affect production of West African Dwarf breed of goats? What is the place of WAD bucks in herd fertility as this breed has shown the potential for improved productivity and the supply of animal protein in the tropics.

This research was therefore conducted to ascertain the reproductive parameters of the WAD bucks based on physiological parameters in the Guinea savannah region of Nigeria. This study was also designed to determine the right and left reproductive parameters and compare them to values of other breeds of goats and ruminants all over the world.

\section{Materials and Methods}

Reproductive parameters (scrotal circumference, testicular density, scrotal weight, left and right testicular weights, left and right tunica weights, left and right testicular length, left and right caput epididymal weights, left and right corpus epididymal weights, left and right caudal epididymal weights) of WAD bucks were collected twice weekly from Modern Market and Wurukum Abattoirs in Makurdi town for a period of three months and evaluated in the College of Veterinary Medicine, University of Agriculture, Makurdi. The age of the animals were determined using dentition estimation method as described by Matika et. al. (1992).

The scrotal circumference was determined by tying a thread round the scrotum with a metre rule (Butswat, 1994). Adhering connective tissues and fat were carefully trimmed. The testes were dissected and epididymis separated. The tunica albuginea of each testis was carefully removed and weighed separately using a "Diamond MCT 500" model electronic density balance. Each component of the epididymis (caput, corpus and cauda), with the tunic and scrotum were weighed using a "Diamond MCT 500" model electronic density balance (Bitto, 1989).The testicular length was measured with a metre rule, while the mean testicular density was determined by dividing the mass of the reproductive organs by their respective volumes as displaced in a cylinder containing water.

Data were subjected to analysis of variance (ANOVA) and significant means were separated using Least Significant Difference according to Minitab (1996).

\section{Results and Discussion}

Table 1 shows the influence of age on the reproductive parameters of WAD bucks. The overall weights of reproductive organs increased with age. The right and left testicular weights, right and left testicular lengths as well as, the right caudal epididymal weights increased as the bucks aged and their values were significantly $(P<0.05)$ different across the three age groups. In the evaluation of breeding soundness of an animal, heavier testes produce 
more spermatozoa than the smaller testes (Brito et. al., 1982). Abdullahi et. al. (2012) recorded that the effect of breed on testicular and epididymal morphometry is essential for a maximal and rational utilization of the breeding stock. Gage and Freckleton (2003) further described the mammalian testes as infallible predictors of spermatozoa production. Masters and Fels (1984) reported that testicular size is controlled by nutrition, even to the extent that well-fed rams in spring may have larger testes than poorly-fed rams in autumn. Testicular values obtained in this study were lower than the values of 134.48 and $154 \mathrm{~g}$ reported by Ahemen and Bitto (2007), and Siddiqui et. al. (2005) for WAD and Kaji rams in Nigeria and Pakistan respectively.

The significant difference $((P<0.05)$ observed between the left and right testes weights is in strong agreement with the study of Ott et. al. (1982) who showed that the left testes was $10 \%$ larger than the right in rams on subsequent examinations. Scrotal circumference is an important indicator when observing animals for breeding soundness; it gives a good indication of rams breeding activity. Scrotal circumference values recorded for the bucks that were less than one year of age were similar with those of one year, and these values were significantly $(\mathrm{P}<0.05)$ lower than values recorded for the two year old bucks.

Scrotal circumference is an important indicator when observing animals for breeding soundness (Orosanye et. al., 2014). It is favourably correlated to testes mass, sperm production, semen quality, age at puberty, body weight and age in young bulls (Swanepoel and Heyns, 1990). Higher scrotal circumference values of $31.25,38.00$ and $35.25 \mathrm{~cm}$ were recorded in Balami, Uda and Yankasa breeds of sheep by Abdullahi et. al. (2012) and these levels were generally higher than values obtained in this study. Ahemen and Bitto (2007) reported paired testis weight and scrotal circumference values of $134.48 \pm 2.28 \mathrm{~g}$ and $21.50 \pm 0.61 \mathrm{~cm}$, while Besta (2006) recorded testes weight of $406 \pm 40 \mathrm{~g}$ in Doper rams of South Africa.

Soderquist and Hulten (2006) reported that for mature rams (17-54 months old), the mean scrotal circumference was $34.4 \pm 2.0 \mathrm{~cm}$ in Gotlandie breed, and $34.5+0.9 \mathrm{~cm}$ for Dorper breed. Abdullahi et. al. (2012) obtained scrotal circumference, mean testes length and mean testes density values of $31.25 \pm 3.18$, $38.00 \pm 0.00, \quad 35.25 \pm 1.77 \mathrm{~cm} ; \quad 12.63 \pm 1.59$, $12.75 \pm 1.06,12.25 \pm 0.35 \mathrm{~cm}$ and $1.03 \pm 0.03$, $1.00 \pm 0.01,1.01 \pm 0.02 \mathrm{~g} / \mathrm{cm}^{3}$ respectively in Balami, Uda and Yankasa breeds of rams. The disparity of the above values from values recorded in this study could be as a result of the species and breed of animals used.

Left caudal epididymal weight values recorded for bucks of less than one year old were significantly $(P<0.05)$ lower than other values which were similar to each other. Also, values of the left caudal epididymal weights recorded for the less than one year and two years old bucks were similar and lower than those of the one year old bucks. Values of most of the reproductive organs of the WAD bucks obtained in this study were similar to values reported by Bitto and Aroh (2006) in Red Sokoto (Maradi) bucks.

\section{Conclusion and Recommendations}

From the forgoing therefore, the observation compared reproductive parameters of WAD bucks of less than one year, one year and two years of age. It equally establishes the baseline for the reproductive parameters in both gonads. The overall weights of reproductive organs of WAD goats increased with age. Values obtained in this work had provided information on the reproductive potential of this breed of goats. Further studies should be carried out to substantiate these figures in the guinea savannah region of Nigeria. 
Ezihe et. al. / Nig. J. Biotech. 32 (2017) 15 - 19

\section{Table 1. Influence of age on the reproductive parameters of the West African dwarf goats (Mean \pm SE)}

\begin{tabular}{|c|c|c|c|c|}
\hline Parameter \Age (years) & $\begin{array}{l}\text { Less than }(<) \text { one } \\
\text { year }\end{array}$ & One year & Two years & $\begin{array}{l}\text { Level of } \\
\text { significance }\end{array}$ \\
\hline Scrotal Circumference (cm) & $18.97 \pm .14^{\mathrm{a}}$ & $18.57 \pm .21^{\mathrm{a}}$ & $23.90 \pm .1 .04^{b}$ & *** \\
\hline Testicular Density $\left(\mathrm{g} / \mathrm{cm}^{3}\right)$ & $1.04 \pm 0.03$ & $1.07 \pm .03$ & $1.09 \pm .0 .03$ & NS \\
\hline Scrotal Weight (g) & $40.00 \pm 2.69^{a}$ & $46.43 \pm 2.28^{b}$ & $48.54 \pm 4.23^{b}$ & NS \\
\hline Left Testicular Weight (g) & $43.61 \pm 3.57^{\mathrm{a}}$ & $53.23 \pm 3.39^{b}$ & $64.67 \pm 3.17^{c}$ & $* * *$ \\
\hline Right Testicular Weight (g) & $48.75 \pm 3.47^{a}$ & $56.63 \pm 3.34^{b}$ & $68.84 \pm 3.24^{c}$ & $* * *$ \\
\hline Left Tunica Weight (g) & $2.05 \pm 0.23$ & $2.44 \pm 0.11$ & $2.07 \pm 0.19$ & NS \\
\hline Right Tunica Weight (g) & $2.28 \pm 0.23$ & $2.44 \pm 0.09$ & $2.70 \pm 0.15$ & NS \\
\hline Left Testicular Length(cm) & $7.60 \pm 0.20^{\mathrm{a}}$ & $8.11 \pm 0.16^{b}$ & $8.93 \pm 0.27^{c}$ & $* *$ \\
\hline Right Testicular Length (cm) & $7.67 \pm 0.21^{\mathrm{a}}$ & $8.17 \pm 0.18^{b}$ & $8.87 \pm 0.27^{c}$ & $*$ \\
\hline Left Caput Epididymal Weight ( $\mathrm{g}$ ) & $0.20 \pm 0.03^{\mathrm{a}}$ & $0.23 \pm 0.02^{\mathrm{ab}}$ & $0.18 \pm 0.01^{\mathrm{a}}$ & $*$ \\
\hline Right Caput Epididymal Weight (g) & $0.16 \pm 0.01$ & $0.15 \pm 0.00$ & $0.17 \pm 0.01$ & NS \\
\hline Left Corpus Epididymal Weight ( $\mathrm{g}$ ) & $0.47 \pm 0.04^{\mathrm{a}}$ & $0.53 \pm 0.22^{\mathrm{ab}}$ & $0.59 \pm 0.04^{b}$ & $*$ \\
\hline Right Corpus Epididymal Weight (g) & $0.47 \pm 0.07$ & $0.50 \pm 0.03$ & $0.62 \pm 0.05$ & NS \\
\hline Left Caudal Epididymal Weight ( $\mathrm{g}$ ) & $2.47 \pm 0.21^{a}$ & $3.00 \pm 0.08^{b}$ & $2.84 \pm 0.16^{\mathrm{ab}}$ & $*$ \\
\hline Right Caudal Epididymal Weight(g) & $2.40 \pm 0.17^{\mathrm{a}}$ & $2.66 \pm 0.08^{b}$ & $3.05 \pm 0.18^{c}$ & $*$ \\
\hline
\end{tabular}

a,b,c: Means $( \pm S E)$ within a row showing different superscripts are significantly different $(P<0.001,0.01$ and $\mathrm{P}<0.05)$

\section{REFERENCES}

Abdullahi, A. A., Aliyu, J., Ashiru, M. and Jamilu, M. (2012). Biometric study of the reproductive organs of three breeds of sheep in Nigeria. Int. J. Morphol, 30(4): $1597-1603$

Ahemen, T. and Bitto, I. I. (2007). Sperm production rate, gonadal and extragonadal sperm reserves of the West African Dwarf rams in Makurdi.Proc.of the $32^{\text {nd }} A n n u$. Conf. of Nig. Soc. for Anim. Prod., March 18 - 21, pp. 99-101
Almquist, J. O., Branas, R. F. and Barber, K. A. (1976). Postpubertal changes in semen production of Charolaise bulls ejaculated at high frequency and the relation between testicular measurements and sperm output. J. Anim. Sci., $42(3): 670-676$

Besta, N. (2006). Effect of different dietary energy levels on productive and reproductive traits in Dorper rams. PhD Thesis, University of the Free State Bloemfontein. 
Ezihe et. al. / Nig. J. Biotech. 32 (2017) 15 - 19

Bitto I.I. (1989). Seasonal Changes in the Physiological and Reproductive Responses of the West African Dwarf buck in Ibadan, Ph.D Thesis University of Ibadan, Ibadan .

Bitto, I. I. and Aroh, V. O. (2006). Testicular morphometry and some biochemical characteristics of testicular spermatozoa and fluids in Red Sokoto (Maradi) bucks. Global J. Agric. Sci., 5(1): $637-642$

Brito, I. F. C., Silva, A. E. D., Unanian, M. M., Dode, M. A. N., Barbos, R. T. and Kastelic, J. P. (1982). Sexual development in early and late maturity Bosindicus and Bosindicus X Bos Taurus cross bred bulls in Brazil. Theriogenology. New York, Elsevier Science Inc. pp.1177 - 1217

Butswat, I.S. (1984). Study on Seasonal Variations in the Reproductive Status of Sheep and Goats in Bauchi, Ph.D. Thesis; ATBU, Bauchi, Nigeria.

Egbunike, G.N., Holtz, W. and Smidt, D. (1976). Reproductive Capacity of German Landrace boars II: Sperm production rates as determined by quantitative testicular histology and from gonadal sperm reserves. Zuchthygeine, 11:35 37

Gage, M. J. and Freckleton, R. P. (2003). Relative Testis size and sperm morphometry across mammals: No evidence for an association between sperm competition and sperm length. Proc. Biol. Sci., 270 (1515):625 - 32

Ibrahim, A. A., Aliyu, J., Ashiru, M. and Jamilu, M. (2012). Biometric study of the reproductive organs of three breeds of sheep in Nigeria. Int. J. Morphol., 30 (4):1597-1603

Igboeli, G. and Rakha, A.M. (1981).Gonadal and Extra-gonadal sperm reserves of indigenous Central African Bulls. T. Fert., 25.107

Masters, D. G. and Fels, H. E. (1984). Seasonal changes in the testicular size of grazing rams. Proc. Aust. Soc. Anim. Prod., 15:444 - 447

Matika, O., Sibanda, R. and Betta, M. L. L. (1992). Eruption of permanent incisors in indigenous goats and sheep: In Small Ruminant Research and Development in Africa. FAO
Corporate Document Depository, ILRI, Matopos Research Station, Bulawayo, Zimbabwe

Minitab (1996). Introduction to statistical quality control. 3rd Edition. John Wiley and Sons.

Orlu, E. E. and Egbunike, G. N. (2010). Breed and seasonal variation in the testicular morphometry, gonadal and extra gonadal sperm reserves of Barred Plymouth Rock and Nigerian indigenous breeds of the domestic fowl. Pak. J. Biol. Sci., 13(3): 120 - 125

Osinowo, E. O., Molokwu, E. C. and Osori, D. C. (1981). Growth and testicular development in Bunaji Bulls. J. Anim. Res., 1 (1):55 - 67

Ososanya, T.O., Adewumi, M. K., Oyeyemi, M. O. and Adeosun, A. O. (2014). Semen characteristics of pubertal West African dwarf rams fed pineapple waste silage as replacement of dried cassava peel. Afri. J. Agric. Res., 9 (4):501 - 506

Ott, R. S., Health, E. H. and Bane, A. (1982). Abnormal spermatozoa, testicular degeneration, and varicocele in a ram. Am. J. Vet. Res., 43(2): $241-245$

Sidddiqui, H.U.R., Ahmad, A. and Khan, M.Z. (2005).Biometrical Studies of Testes of Ram.Short communication.J. Agric. Soc. Sci., 1 (1):78 - 79

Soderquist, L. and Hulten, F. (2006). Normal values for the scrotal circumference in rams of Gotlandic breed. Reprod. Domest. Anim. 41(1):61 - 62

Swanepoel, F. J. C. and Heyns, H. (1990). Scrotal circumference in young beef bulls: relationships to growth traits. Proc. $4^{\text {th }}$ World Congr. Genet. Appl. Livest. Prod., 13:275-280

Togun, V.A. and Egbunike, G. N. (2006).Seasonal variations in the sperm production characteristics of Zebu (white Fulani) cattle genitalia in the humid tropical environment. Middle-East J. Sci. Res., 1(1): 87 95 